\title{
Cold sweetening diversity in Andean potato germplasm from Argentina
}

\author{
Silvana L. Colman ${ }^{1,2 \S}$, Gabriela A. Massa ${ }^{1,2,3}$, Martín F. Carboni ${ }^{1,2}$ and Sergio E. \\ Feingold ${ }^{1, *}$ \\ ${ }^{1}$ Laboratorio de Agrobiotecnología, Instituto Nacional de Tecnología Agropecuaria \\ (INTA), EEA Balcarce CC 276 (7620), Balcarce, Argentina \\ ${ }^{2}$ Consejo Nacional de Investigaciones Científicas y Técnicas (CONICET), Argentina \\ ${ }^{3}$ Facultad de Ciencias Agrarias, Universidad Nacional de Mar del Plata, Balcarce, \\ Argentina \\ $\S$ Present address: Instituto de Investigaciones Biológicas-Consejo Nacional de \\ Investigaciones Científicas y Técnicas, Universidad Nacional de Mar del Plata (IIB- \\ CONICET, UNMdP), Argentina \\ *Corresponding author: feingold.sergio@inta.gob.ar
}

Telephone number: 542266439100

Fax: 542266439101

\begin{abstract}
BACKGROUND: Cold-induced sweetening (CIS) is the accumulation of sucrose and reducing sugars in potato tubers at low temperatures. This process is central for the potato processing industry. During potato chip and French fry production, reducing sugars participate in the Maillard reaction to produce dark pigmented products not acceptable to consumers. Andean potatoes (Solanum tuberosum Group Andigena)
\end{abstract}

This article has been accepted for publication and undergone full peer review but has not been through the copyediting, typesetting, pagination and proofreading process, which may lead to differences between this version and the Version of Record. Please cite this article as doi: $10.1002 /$ jsfa. 8343

This article is protected by copyright. All rights reserved. 
constitute an enormous wealth of potato germplasm that can contribute to increase genetic diversity in breeding programs of many traits, including CIS.

RESULTS: We analyzed reducing sugar content and chip quality in freshly harvested and cold stored tubers from 48 native accessions. Andean accessions showed high variation in reducing sugar content and were classified in three types of CIS responses, I- Reducing sugar content before and after $4{ }^{\circ} \mathrm{C}$ storage was lower than the value required by industry; II- reducing sugar content before storage was acceptable, but after $4{ }^{\circ} \mathrm{C}$ storage incremented up to non-acceptable levels; and III- reducing sugar content was unacceptable before and after storage.

CONCLUSION: Five Andean accessions presented acceptable reducing sugar content and good chip quality before and after $4{ }^{\circ} \mathrm{C}$ storage in a consistent manner throughout several experiments. These features make them a useful source for improving potato industry.

\section{KEYWORDS}

Cold sweetening; Andean potatoes; reducing sugars; chip color

This article is protected by copyright. All rights reserved. 


\section{INTRODUCTION}

Potato (Solanum tuberosum) is a native crop from South American highlands that has become the most consumed non-grain food product worldwide (http://faostat3.fao.org). In order to maintain continuous supply of potato throughout the year, potato tubers are often stored at low temperatures. Without cold storage, potatoes have a shelf life of about six months after which their quality rapidly deteriorates. ${ }^{1}$ Cold temperature reduces sprouting, losses due to dehydration and respiration, and the spread of diseases. One undesirable consequence of cold storage $\left(<10^{\circ} \mathrm{C}\right)$ is a phenomenon named coldinduced sweetening (CIS), in which reducing sugars (glucose and fructose), mainly derived from sucrose hydrolysis accumulate in the tubers. ${ }^{2}$ CIS is an hereditable trait ${ }^{3}$ and has been explained as an adaptive response to stress caused by cold temperatures. ${ }^{4}$ Reducing sugars negatively influence potato chip and French fry quality, as they react during processing with amino acids in the Maillard reaction, ${ }^{5}$ resulting in brown- to black-colored food products that are not acceptable to consumers. ${ }^{2}$ Additionally, Maillard reaction also generates acrylamide a neurotoxin and a possible human carcinogen. ${ }^{6}$ Therefore, preventing reducing sugar accumulation during tuber storage is of economic and nutritional importance to the potato processing industry and one of the main objectives of breeding programs in the world. ${ }^{7}$

Solanum tuberosum Group Andigena comprises native cultivars derived from domestication and selection by Andean farmers ancestrally in the past 7000 years. They are cultivated under short day conditions along the Andes at heights ranging from 2,000 to $4,000 \mathrm{msnm}^{8-9}$ In Argentina, potato landraces are grown in Northwestern provinces (NWA), mainly in Jujuy, Salta and Catamarca. ${ }^{10}$ Group Andigena comprises highly polymorphic tetraploid genotypes ${ }^{9,11}$ that show variation in their growth habitat, flower color and tuber characteristics. The high diversity of this Group was demonstrated by

This article is protected by copyright. All rights reserved. 
studies with morphological descriptors and molecular markers ${ }^{9,}{ }^{12-15}$ constituting an enormous wealth of potato germplasm that can contribute to increase genetic diversity in breeding programs of many traits, including CIS.

In this work we have analyzed 48 accessions of potato varieties from S. tuberosum Group Andigena in relation with CIS response. Each accession correspond to a single, vegetative propagated clone maintained by the Active Germplasm Bank of INTA-EEA Balcarce that were collected from different locations in Jujuy and Salta provinces of Argentina. They were selected based on their genetic polymorphism, previously analyzed with set of microsatellites. ${ }^{14}$

The aim of this three-year study was to characterize CIS in Andean germplasm through analyzing reducing sugar content and chip quality of freshly harvested and cold stored tubers.

\section{MATERIALS AND METHODS}

\section{Plant material}

A total of 48 accessions (Solanum tuberosum Group Andigena) deposited in the Active Germplasm Bank of INTA-EEA Balcarce (BAL), Argentina were used (Table 1). Plant material from in vitro collection was sown in counter season in a greenhouse for tuber multiplication. Three field trials in randomized blocks with two replications were conducted from November to April of the following year in three consecutive seasons (2010-2011, 2011-2012 and 2012-2013). The first two trials were planted in an experimental field in Humahuaca $\left(23^{\circ} 12^{\prime} 5^{\prime \prime} \mathrm{S}, 6^{\circ} 21^{\prime} 0^{\prime \prime} \mathrm{O}, 2939\right.$ MAMSL), Jujuy, Argentina, and the third one in a field located in Yavi Department $\left(22^{\circ} 6^{\prime} 4^{\prime \prime} \mathrm{S}\right.$, $65^{\circ} 35^{\prime} 44^{\prime \prime}$ O, 3377 MAMSL), Jujuy, Argentina. We planted 30 accessions in the first field trial increasing the number of accessions through seasons, as they become available, to end up with 48 accessions in the last trial.

This article is protected by copyright. All rights reserved. 
Environmental conditions of this region (NW of Argentine) are favorable for Andean tubers production. Local potato cultivation procedures were used.

After harvesting, all tubers were maintained at room temperature until processing (ca. $20{ }^{\circ} \mathrm{C}$ ). Then, 10 healthy tubers from each accession were selected and stored at $4{ }^{\circ} \mathrm{C}$ at high relative humidity in the dark. Phenotypic characterization was performed before (freshly harvest) and after two months of storage at $4{ }^{\circ} \mathrm{C}$. Three healthy tubers of each condition were selected for the analysis, sliced in half from apical end to basal bud and then processed to $1.5-2 \mathrm{~mm}$ thickness. The slices were frozen in liquid nitrogen and stored at $-80{ }^{\circ} \mathrm{C}$.

\section{Extraction and quantification of reducing sugars}

Reducing sugar content was determined as described by Ohara-Takada et al., ${ }^{16}$ For reducing sugar extraction we used a sample of three frozen slices (one from each tuber). The sample (ca. $5 \mathrm{~g}$ fresh weight) was homogenized with an Ultra-Turrax disperser (IKA, Germany) for $5 \mathrm{~min}$ in $15 \mathrm{~mL} 80 \%$ ethanol, and sugars in the homogenate were extracted at $80{ }^{\circ} \mathrm{C}$ for one hour. The extract was filtered through four layers of gauze, and then centrifuged at $10,000 \mathrm{~g}$ at $4{ }^{\circ} \mathrm{C}$ for $20 \mathrm{~min}$. The supernatant was filtered by Strata Sax $55 \mu \mathrm{m}, 70 \mathrm{~A}$ column (Phenomenex, EEUU) and a $0.2 \mu \mathrm{m}$ membrane filter (Microclar, Argentina). Glucose and fructose content were determined by high performance liquid chromatography (HPLC HP, EEUU) with an Amide-80 column (Phenomenex, Luna 5u NH2 100A, 250 x $4.60 \mathrm{~mm} 5$ micron, EEUU). The mobile phase was $80 \%$ acetonitrile/water, and the pump was set at a flow rate of $1 \mathrm{~mL} \mathrm{~min}^{-1}$.

Quantification of reducing sugar was performed by standardization with $0.50 \mathrm{mg} \mathrm{mL} \mathrm{m}^{-1}$ external glucose and fructose (Merck, Germany).

\section{Preparation of potato chips and chip color determination}

This article is protected by copyright. All rights reserved. 
Twelve fresh slices (four from each tuber) were used for chip production. Tuber slices were water rinsed for 2 min and the surface was dry off with paper towels. Tuber slices were fried at $180{ }^{\circ} \mathrm{C}$ for 2 min or until bubbles were not observed in the oil. Chips were drained and placed on a white surface for observation. Chip color was visually determined with the color cards developed by the Institute for Storage and Processing of Agricultural Produce (Wageningen-The Netherlands), being a score of 9 the lightest and 1 the darkest.

\section{Data analysis}

The correlation analysis and means calculi were performed using Prims 5 for Windows software version 5.01. Values were expressed as the means \pm standard deviation (SD). In all cases, the confidence coefficient was set at 0.05 . Correlation analysis was used to establish the relationship between reducing sugars and chip quality scores. All mean comparisons were carried out using analysis of variance (ANOVA) with Infostat Software (2003 version, www.infostat.com.ar).

\section{RESULTS AND DISCUSSION}

To study CIS response we used tubers harvested from three field trials. Reducing sugar content was quantified in two conditions: before (freshly harvested tubers) and after 4 ${ }^{\circ} \mathrm{C}$ storage for two months. Interaction between reducing sugar content and location/year was not significant $(\mathrm{p}>0.1)$; therefore we have used the average values of all field trials. Native accessions showed high variation in reducing sugar content of both freshly harvested and $4{ }^{\circ} \mathrm{C}$ stored tubers (Fig. 1). Freshly harvested tubers presented an overall reducing sugar average of $2.08 \pm 1.23 \mathrm{~g} \mathrm{~kg}^{-1} \mathrm{FW}$, while after $4{ }^{\circ} \mathrm{C}$ storage, this value was significantly incremented to $6.64 \pm 3.49 \mathrm{~g} \mathrm{~kg}^{-1} \mathrm{FW}$. Different accessions showed reducing sugar content in $4{ }^{\circ} \mathrm{C}$ stored tubers varying from 1.09 to $16.65 \mathrm{~g} \mathrm{~kg}^{-1} \mathrm{FW}$ (Fig. 1).

This article is protected by copyright. All rights reserved. 
Although critical values for fried products differ according processing company standards, it is accepted that reducing sugar content over $2.5 \mathrm{~g} \mathrm{~kg}^{-1} \mathrm{FW}$ are not acceptable for the industry. ${ }^{4,17-18}$ Particularly, for chip preparation minor values are desired, since chips are more susceptible to the problem of high reducing sugar concentration than French fries. ${ }^{19}$ CIS response in the Andean accessions before and after storage can be classified in three types of responses (Fig. 1). Samples from 5 accessions showed a type I response, in which reducing sugar content before and after 4 ${ }^{\circ} \mathrm{C}$ storage were below $2.5 \mathrm{~g} \mathrm{~kg}^{-1} \mathrm{FW}$. Thus, accessions CL 641, CCS 1350, CL 650, CCS 1384 and CCS 1199 can be considered as CIS resistant. Twenty six accessions showed a type II response, were reducing sugar contents before storage was acceptable, but after $4{ }^{\circ} \mathrm{C}$ storage reducing sugar contents incremented up to non-acceptable levels. Finally, 17 accessions had a type III response, were reducing sugar levels were higher than $2.5 \mathrm{~g} \mathrm{~kg}^{-1} \mathrm{FW}$ before and after $4{ }^{\circ} \mathrm{C}$ storage

We evaluated chip quality from freshly harvested and $4{ }^{\circ} \mathrm{C}$ stored tubers by their color according to a 9 to 1 scale (Institute for Storage and Processing of Agricultural Produce; Wageningen, The Netherlands). The chips industry regards card 5 as showing the darkest acceptable color. ${ }^{20}$ Freshly harvested tubers produced light colored chips, with an average score of 7 . When tubers were stored at $4{ }^{\circ} \mathrm{C}$ chip quality decreased and the average score fell to a value of 3.8 (Fig. 2). Different accessions showed great color diversity before and after $4{ }^{\circ} \mathrm{C}$ storage with scores that ranged from 1 to 8 . Among them, accessions CCS 1330, CCS 1199, CCS 1384 and LC 348 produced good quality chips with scores of 8 even after $4{ }^{\circ} \mathrm{C}$ storage (Fig. 3). Chip color evaluation was difficult in accessions CL 658 and CCS 1385 due to their pink and violet flesh, respectively. In these cases, we only used reducing sugar content to evaluate the CIS response, and these accessions are not included in Figure 2.

This article is protected by copyright. All rights reserved. 
Several reports indicate that reducing sugar content is the most important factor governing color of processed product. ${ }^{21}$ In this study, there was a significant $(\mathrm{p}<0.001)$ negative relationship between chip color score and reducing sugar content since the scale uses high scores for light and low scores for dark colors. The correlation coefficients of chip color scores with reducing sugar content in freshly harvested and 4 ${ }^{\circ} \mathrm{C}$ stored tubers were -0.63 and -0.69 , respectively. These values were within the range of correlation values (0.47-0.92) previously reported. ${ }^{22-23}$ Regressions of reducing sugar content with chip color scores were explained by exponential functions in both conditions, freshly harvested $\left(\mathrm{R}^{2}=0.41\right)$ and $4{ }^{\circ} \mathrm{C}$ stored tubers $\left(\mathrm{R}^{2}=0.55\right)($ Fig. 4$)$.

Seven accessions showed chip color of 7 or above after cold storage (Fig. 2). Four out of the five accessions that presented a type I response, were included in this group, presenting CL 641 a color score after storage of 6 . The four most CIS resistant Andean accessions evaluated by chip color were CCS 1330, CCS 1199, CCS 1384 and LC 348 presented scores of 8 after storage (Fig. 2 and 3). Interestingly, CCS 1330 and LC348 grouped in type II response-presented an average reducing sugar content of 2.63 and 3.48 g kg-1 FW after storage, respectively (Fig. 1). These results, evidence that although, chip color can be explained in a large extent by reducing sugar content, can also be affected by other compounds as polyphenols, amino acids (lysine, glycine, glutamine and arginine) and proteins present in potato tubers ${ }^{24}$ that were not determined in this study. Also, color score is a subjective measurement that can be improved by automatic determinations using colorimeters. ${ }^{25}$

Several reports determine sucrose content -the substrate of invertases for glucose and fructose by hydrolisis- as a potential of accumulation of reducing sugars during storage of tubers. ${ }^{22-23,}{ }^{26-28}$ Also, McCann et al., ${ }^{23}$ reported significant correlations between sucrose and chip color in some accessions of S. pinnatisectum, which supports the 
hypothesis that hydrolysis of sucrose may occur during frying and that these newly created reducing sugars contribute to chip darkening. However, another work demonstrated that invertase gene silencing caused higher accumulation of sucrose and lower amounts of glucose and fructose resulting in better quality chips than untransformed controls during cold storage. ${ }^{29}$ In our work, sucrose concentrations varied widely among the accessions. Mean sucrose concentrations in fresh harvested tubers ranged from 0.75 to $7.77 \mathrm{~g} \mathrm{~kg}^{-1} \mathrm{FW}$, similar to cold stored tubers, which varied from 0.88 to $7.9 \mathrm{~g} \mathrm{~kg}^{-1} \mathrm{FW}$. Likewise, we have not found significantly correlation between sucrose content and chip color. Since sucrose does not react directly in the Maillard reaction ${ }^{5}$ it is expected that sucrose concentration has little or no correlation with chip color.

\section{CONCLUSIONS}

The use of native and wild germplasm has been proposed as a source of CIS resistance

to improve chip quality ${ }^{23,26-28}$ This work, the first characterizing CIS in a large number of Andean accessions, showed a wide variety of responses for this phenomenon. Several accessions presented acceptable reducing sugar content and good chip quality before and after $4{ }^{\circ} \mathrm{C}$ storage in a consistent manner throughout several experiments comprising different years and locations. These features make them a useful source for improving potato using both, conventional breeding or through the aid of molecular techniques.

\section{ACKNOWLEDGMENTS}

We would like to thank Active Germplasm Bank from INTA Balcarce for provided the plant material. We also acknowledge Laboratory of Quality and Postharvest Technology

This article is protected by copyright. All rights reserved. 
from INTA Balcarce for analytical determinations of reducing sugars. We thank Silvina

Divito for her technical assistance and Escuela Agrotécnica $\mathrm{N}^{\mathrm{o}} 3$ for provide the field for the trials.

\section{FUNDING SOURCES}

This work was funded by Instituto Nacional de Tecnología Agropecuaria (INTA) through internal funds AETA282811 and PNAIyAV1130043, Facultad de Ciencias Exactas y Naturales-UNMdP Extension Project CEN-013-2012 and Ministerio Nacional de Ciencia y Técnica (MINCyT) of Argentina through competitive grant PICT 20102037. SLC and MFC hold a doctoral fellowship from Consejo Nacional de Investigaciones Científicas y Técnicas (CONICET) ARGENTINA.

\section{REFERENCES}

1. Bianchi G, Scalzo R, Testoni A and Maestrelli A, Nondestructive analysis to monitor potato quality during cold storage. J Food Qual 37:9-17 (2014).

2. Dale MFB and Bradshaw JE, Progress in improving processing attributes in potato. Trends in Plant Science 8:310-312 (2003).

3. Menendez CM, Ritter E, Schafer-Pregl R, Walkemeier B, Kalde A, Salamini F and Gebhardt $C$, Cold sweetening in diploid potato: mapping quantitative trait loci and candidate genes. Genetics 162:1423-1434 (2002).

4. Burton WG, The sugar balance in some British potato varieties during storage. II. The effects of tuber age, previous storage temperature, and intermittent refrigeration upon low-temperature sweetening. Potato Research 12:81-95 (1969).

5. Shallenberger RS, Smith O and Treadway RH, Food Color Changes, Role of the Sugars in the Browning Reaction in Potato Chips. Journal of Agricultural and Food Chemistry 7:274-277 (1959).

6. Jackson LS, Chemical food safety issues in the United States: past, present, and future. J Agric Food Chem 57:8161-8170 (2009).

7. Kawchuk L, Lynch D, Yada R, Bizimungu B and Lynn J, Marker assisted selection of potato clones that process with light chip color. American Journal of Potato Research 85:227-231 (2008).

8. Hawkes JG, The potato: evolution, biodiversity and genetic resources. Belhaven Press (1990).

9. Sukhotu T and Hosaka K, Origin and evolution of Andigena potatoes revealed by chloroplast and nuclear DNA markers. Genome 49:636-647 (2006).

10. Viirsoo E, Comportamiento de especies silvestres tuberíferas y de formas autóctonas del género Solanum en las montañas de Catamarca. IDIA (Argentina) 231:1631 (1967).

This article is protected by copyright. All rights reserved. 
11. Ugent D, Solanum raphanifolium, a Peruvian wild potato species of hybrid origin Bot Gazette 3:225-233 (1970).

12. Ispizua VN, Guma IR, Feingold S and Clausen AM, Genetic diversity of potato landraces from northwestern Argentina assessed with simple sequence repeats (SSRs). Genetic Resources and Crop Evolution 54:1833-1848 (2007).

13. Ghislain M, Núñez J, del Rosario Herrera $M$ and Spooner DM, The single Andigenum origin of Neo-Tuberosum potato materials is not supported by microsatellite and plastid marker analyses. Theoretical and Applied Genetics 118:963-969 (2009).

14. Atencio M, Diversidad en variedades andinas de papa (Solanum tuberosum ssp. andigena) evaluada con microsatélites, Ed. Universidad Nacional de Mar del Plata, Balcarce (2011).

15. Gavrilenko T, Antonova O, Shuvalova A, Krylova E, Alpatyeva N, Spooner DM and Novikova L, Genetic diversity and origin of cultivated potatoes based on plastid microsatellite polymorphism. Genetic Resources and Crop Evolution 6o:1997-2015 (2013).

16. Ohara-Takada A, Matsuura-Endo C, Chuda Y, Ono H, Yada H, Yoshida M, Kobayashi A, Tsuda S, Takigawa S and Noda T, Change in content of sugars and free amino acids in potato tubers under short-term storage at low temperature and the effect on acrylamide level after frying. Bioscience, biotechnology, and biochemistry 69:1232-1238 (2005).

17. Moreira RG, Castell-Perez ME and Barrufet MA, Deep-fat Frying: Fundamentals and Applications. Aspen, Gatihersburg, (1999).

18. Kumar D, Paul V and Ezekiel R, Chipping quality of potatoes stored in heaps and pits in subtropical plains of India. Hort Sci (Prague) 32:23-30 (2005).

19. Misener G, Gerber W, Tai G and Embleton E, Measurement of glucose concentrations of potato extract using a blood glucose test strip. Canadian Agricultural Engineering 38:59-62 (1996).

20. Olsson K, Svensson R and Roslund C-A, Variation in tuber components affecting acrylamide formation and colour in fried potato, in Meeting of the Physiology Section of the European Association for Potato Research 684, Ed, pp 159-164 (2004).

21. Kumar D, Singh B and Kumar P, An overview of the factors affecting sugar content of potatoes. Annals of Applied Biology 145:247-256 (2004).

22. Mazza $G$, Correlations between quality parameters of potatoes during growth and long-term storage. American potato journal 6o:145-159 (1983).

23. McCann LC, Bethke PC and Simon PW, Extensive variation in fried chip color and tuber composition in cold-stored tubers of wild potato (Solanum) germplasm. Journal of Agricultural and Food Chemistry 58:2368-2376 (2010).

24. Rodriguez-Saona LE and Wrolstad RE, Influence of potato composition on chip color quality. American potato journal 74:87-106 (1997).

25. Pedreschi F, Mery D and Marique T, Quality evaluation and control of potato chips and French fries. Computer vision technology for food quality evaluation:545-566 (2007).

26. López R, Barandalla L, Ritter E, Hasse U and Ruiz de Galarreta J, Evaluación del valor nutricional de germoplasma nativo de patata para su incorporación en programas de mejora genética. Revista Latinoamericana de la Papa 15:55-57 (2009).

27. Jansky SH, Hamernik A and Bethke PC, Germplasm release: Tetraploid clones with resistance to cold-induced sweetening. American Journal of Potato Research 88:218225 (2011).

28. Zhao Q, Zhao B, Zhang Q, Yu B, Cheng L, Jin R, Wang Y, Zhang J, Wang D and Zhang F, Screening for Chip-Processing Potato Line from Introgression of Wild Species' Germplasms with Post-Harvest Storage and Chip Qualities. American Journal of Potato Research 90:425-439 (2013).

This article is protected by copyright. All rights reserved. 
29. Bhaskar PB, Wu L, Busse JS, Whitty BR, Hamernik AJ, Jansky SH, Buell CR, Bethke PC and Jiang J, Suppression of the vacuolar invertase gene prevents cold-induced sweetening in potato. Plant physiology 154:939-948 (2010).

Table 1. Accessions planted in field trials. Accessions were provided by Active Germplasm Bank of INTA-EEA Balcarce (BAL), Argentina.

\begin{tabular}{|c|c|c|c|}
\hline Accessions analyzed & Province & Department & Locality \\
\hline CCS 1350 Blanca alargada & Jujuy & Tumbaya & El Angosto \\
\hline CS 1418 Chaqueña & Jujuy & General Belgrano & Papachacra \\
\hline CS 1432 Collareja redonda & Jujuy & General Belgrano & Cuevas \\
\hline CCS 1172 Moradita redonda & Jujuy & Tilcara & Casa Colorada \\
\hline CCS 1251 Chacarera & Jujuy & Cochinoca & Cochinoca \\
\hline CCS 1330 Moradita & Jujuy & Cochinoca & Rachaite \\
\hline CCS 1307 Moradita & Jujuy & Santa Catalina & Cabreria \\
\hline CCS 1166 Cuarentona colorada & Jujuy & Tilcara & Casa Colorada \\
\hline CS 1419 Blanca & Jujuy & General Belgrano & Papachacra \\
\hline CCS 1199 Tuni blanca & Jujuy & Humahuaca & Palca de Aparzo \\
\hline CCS 1349 Colorada & Jujuy & Tumbaya & El Angosto \\
\hline CCS 1185 Tuni morada & Jujuy & Humahuaca & Aparzo \\
\hline CCS 1201 Azul & Jujuy & Humahuaca & Varas \\
\hline CS 1430 Cuarentona & Jujuy & General Belgrano & Cuevas \\
\hline CL 658 Santa Maria & Jujuy & Yavi & Yavi \\
\hline CCS 1283 Waicha & Jujuy & Yavi & Yavi \\
\hline CCS 1295 Rosada & Jujuy & Santa Catalina & Casira \\
\hline CCS 1371 Chacarera & Jujuy & Cochinoca & Quebraleña \\
\hline CCS 1205 Churqueña & Jujuy & Humahuaca & Varas \\
\hline CCS 1247 Tuni blanca & Jujuy & Cochinoca & Ojo de Agua \\
\hline CL 621 Chorcoyeña & Salta & Santa Victoria & Nazareno \\
\hline CCS 1271 Blanca & Jujuy & Santa Catalina & Morco Esquina \\
\hline CCS 1284 Sani & Jujuy & Yavi & Yavi \\
\hline CCS 1366 Overa & Jujuy & Tumbaya & El Moreno \\
\hline CCS 1327 Bayista & Jujuy & Cochinoca & Rachaite \\
\hline CCS1381 Runa & Jujuy & Tumbaya & Patacal \\
\hline CL 728 Cuarentona & Salta & Iruya & Colanzulí \\
\hline CL 482 Rosada & Salta & Santa Victoria & Rodeopampa \\
\hline CCS 1383 Pera o señorita & Jujuy & Tumbaya & Patacal \\
\hline CCS 1323 Colorada & Jujuy & Cochinoca & Agua Caliente \\
\hline CCS 1303 Yuruma & Jujuy & Santa Catalina & Casira \\
\hline CCS 1374 Moradita & Jujuy & Cochinoca & Agua Castilla \\
\hline CL 631 Allo & Salta & Iruya & Campo Carreras \\
\hline CCS 1384 Corbatilla & Jujuy & Tumbaya & Patacal \\
\hline CCS 1385 Moradita & Jujuy & Tumbaya & Patacal \\
\hline CL 516 Chorcoyeña & Salta & Santa Victoria & Chorro \\
\hline
\end{tabular}

This article is protected by copyright. All rights reserved. 


$\begin{array}{llll}\text { CL 650 Colorada } & \text { Salta } & \text { Santa Victoria } & \text { Trigohuaico } \\ \text { CL 576 Runa } & \text { Salta } & \text { Santa Victoria } & \text { Lizoite } \\ \text { CL 641 Runa } & \text { Salta } & \text { Santa Victoria } & \text { Poscaya } \\ \text { CL 835 Airampia } & \text { Jujuy } & \text { Valle Grande } & \text { Santa Ana } \\ \text { CL 790 Overa } & \text { Jujuy } & \text { Valle Grande } & \text { Santa Ana } \\ \text { CCS 1170 Ojos colorados } & \text { Jujuy } & \text { Tilcara } & \text { Casa Colorada } \\ \text { CL 836 Airampia } & \text { Jujuy } & \text { Valle Grande } & \text { Santa Ana } \\ \text { CL 708 Runa } & \text { Salta } & \text { Iruya } & \text { Colanzulí } \\ \text { CL 820 Negra redonda } & \text { Jujuy } & \text { Valle Grande } & \text { Santa Ana } \\ \text { CCS 1309 Blanca redonda } & \text { Jujuy } & \text { Santa Catalina } & \text { Cabreria } \\ \text { CCS 1224 Collareja } & \text { Jujuy } & \text { Humahuaca } & \text { Coctaca } \\ \text { LC 348 Imilla negra } & \text { Jujuy } & \text { Humahuaca } & \text { Huachichocana }\end{array}$

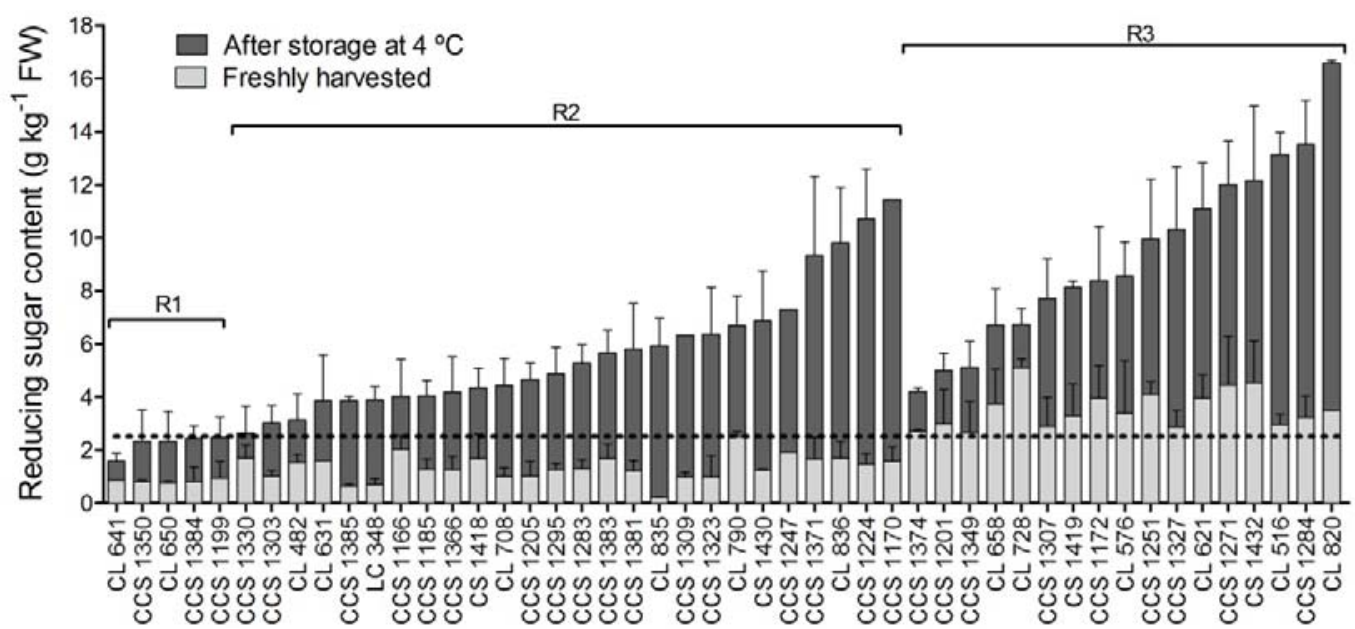

Figure 1. Reducing sugar content $\left(\mathrm{g} \mathrm{kg}^{-1} \mathrm{FW}\right)$ and cold sweetening responses (R1, R2 and R3) of freshly harvested (clear bars) and cold stored tubers (dark bars). Bars show mean values and lines \pm standard deviations. Dotted line at $2.5 \mathrm{~g} \mathrm{~kg}^{-1} \mathrm{FW}$ indicates highest reducing sugar content acceptable by industry.

This article is protected by copyright. All rights reserved. 


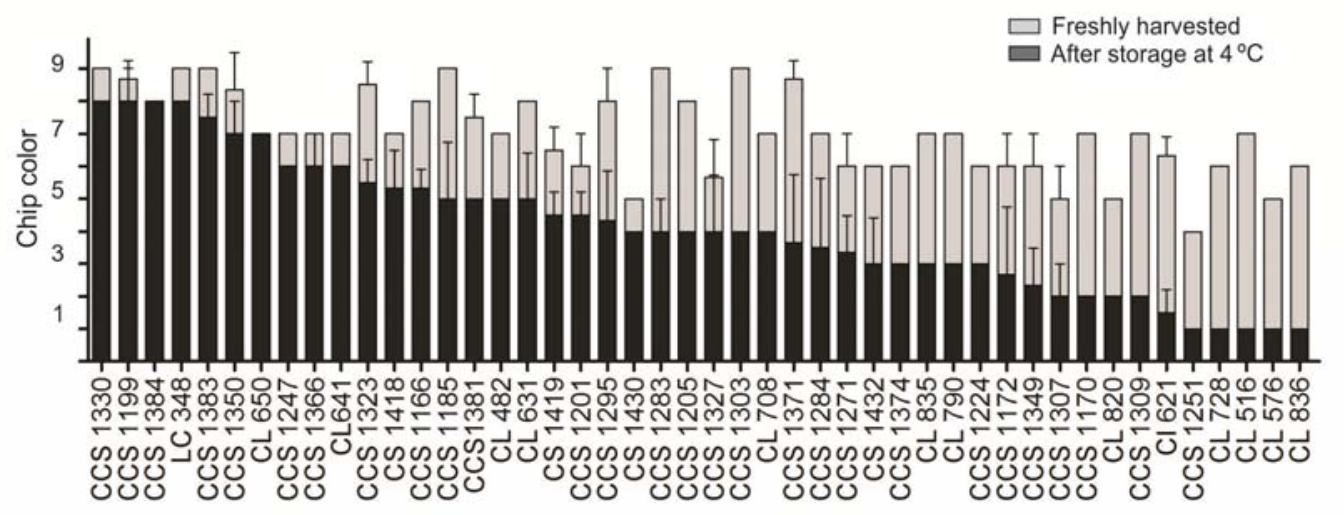

Figure 2. Chip color means from freshly harvested (clear bars) and cold stored (dark bars) tubers. Tubers were stored at $4^{\circ} \mathrm{C}$ for two months. Chip color was visually determined with color cards developed by the Institute for Storage and Processing of Agricultural Produce (Wageningen-The Netherlands), where a score of 9 is lightest and 1 is darkest.

This article is protected by copyright. All rights reserved. 


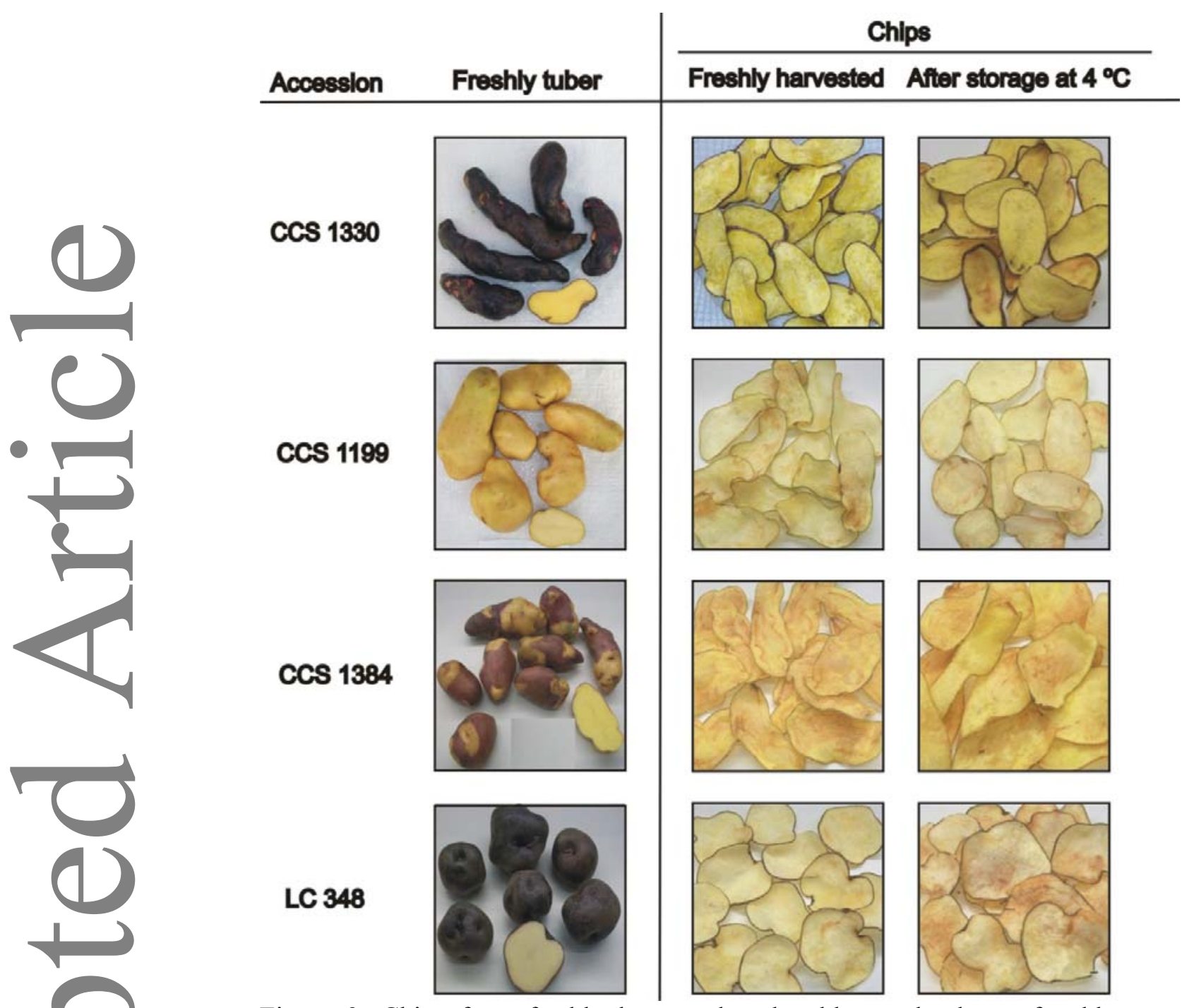

Figure 3. Chips from freshly harvested and cold stored tubers of cold sweetening resistant accessions evaluated by chip color score.
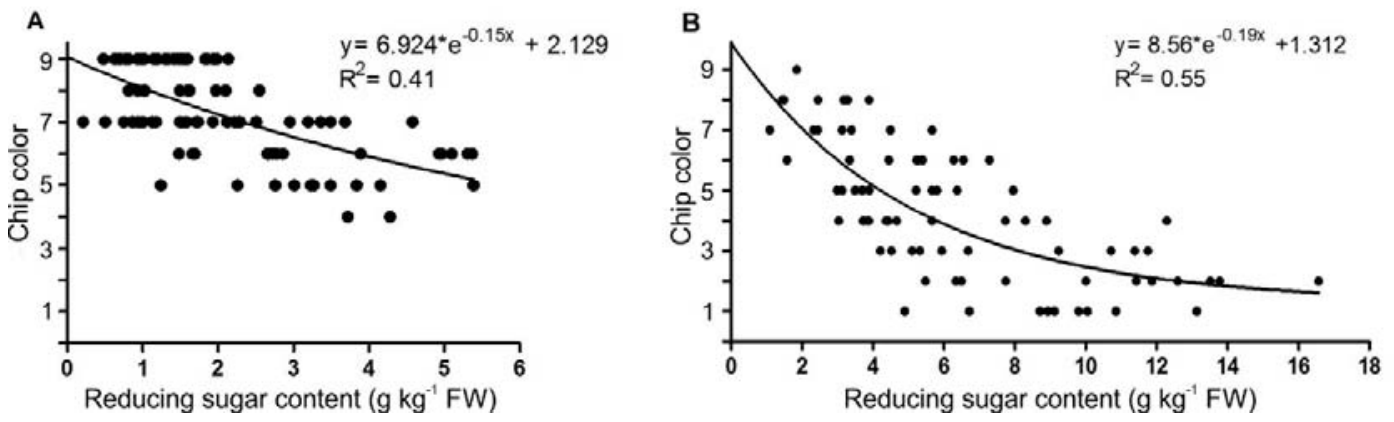

This article is protected by copyright. All rights reserved. 
